\title{
Dairy-Beef Cattle Situation in Thailand
}

\section{Jamsawat $\mathrm{V}^{*}$}

Faculty of Agriculture and Natural Resourse, Rajamangala University of Technology Tawan-ok, Thailand

*Corresponding author: Virapol Jamsawat, Faculty of Agriculture and Natural Resourse, Rajamangala University of Technology Tawan-ok, Thailand, Email: virapolj@yahoo.com

\section{Editorial}

Volume 3 Issue 2

Received Date: September 11, 2020

Published Date: September 16, 2020

DOI: $10.23880 /$ oajmms-16000128

\section{Editorial}

Thailand is an agricultural country. Livestock production plays an important role both in supplying meat, milk, and eggs for domestic consumption and for export. Livestock are used for multiple purposes such as draught power, a means of transportation, capital, credit, meat, milk, social value, by-product uses. Diversity of livestock in terms of species, distribution, roles, etc., can be widely found and is integrated into the prevailing production systems throughout the country. In general, two groups of animals have been raised, ruminants; beef cattle, dairy cattle, swamp buffaloes, sheep and goats and non-ruminants: swine and poultry. The status of animal production are dependent on the two part of producer farmer. There are small holder farmer and private sector companies. The all of ruminant farm such as dairy cattle, beef cattle, buffalo, sheep and goat farm are small holder farmer and the most of non-ruminant farm such as swine and poultry are the large companies.

In dairy cattle farm, the breeds of these cattle are Holstien
Frishien (HF) and their cross bred with American Brahman or Native Thai breed (75-100\% of blood HF). In beef cattle farm, the most of them are American Brahman breed and their cross breed with Native Thai. American Brahman breed were promoted more than 50 years ago by Department of Livestock, Ministry of Agriculture and Cooperatives of Thai government. But the most of buffalo population are swamp buffalo as local breed or Pluk buffalo (call in Thai).There are some private farms started to promote Buffalo milk by import Murrah Buffalo for milk production that support by University as RMUTTO Jamsawat V, et al.

\section{Animal and People Population of Thailand}

Thailand population in 2020 is actually nearer 66 million. It's estimated there are 2.2 million illegal and legal migrants in Thailand, The small holder animal farmer family are 2.9 million. Particularly, Farmer family population, livestock population and their production potential as well as breeding services coverage were presented as below (Table 1).

\begin{tabular}{|c|c|c|}
\hline Farmer (Family) & Livestock Population (head) & Population (head) \\
\hline 768,834 & Beef cattle & $4,530,915$ \\
\hline 17,094 & Diary cattle & 512,205 \\
\hline 194,508 & Buffalo & 877,364 \\
\hline 210,978 & Pig & $9,511,389$ \\
\hline 5,170 & Sheep & 42,040 \\
\hline 41,674 & Goat & 440,277 \\
\hline $2,288,328$ & chicken & $377,563,198$ \\
\hline
\end{tabular}

Table 1: Animal and farmer population of Thailand.

\section{Beef Production in/K Thailand}

The population reported in 2014 was 5.7 and 1.9 million head for cattle and buffaloes respectively. During the period 1993 to 1998, cattle numbers increased but declined markedly thereafter of period 2012-2016 (Table 2). 


\section{Open Access Journal of Mycology \& Mycological Sciences}

\begin{tabular}{|c|c|c|c|c|c|}
\hline Years & $\mathbf{2 0 1 4}$ & $\mathbf{2 0 1 5}$ & $\mathbf{2 0 1 6}$ & $\mathbf{2 0 1 7}$ & $\mathbf{2 0 1 8}$ \\
\hline Cattle (head) & 1.06 & 1.05 & 1.06 & 1.07 & 1.08 \\
\hline Carcass weight (metric ton) & 169.71 & 167.23 & 168.1 & 168.34 & 170.65 \\
\hline Domestic consumption-(million head/year) & 1.248 & 1.243 & 1.245 & 1.253 & 1.262 \\
\hline -Carcass weight (metric ton) & 178.25 & 177.5 & 177.75 & 177.45 & 179.8 \\
\hline
\end{tabular}

Table 2: Beef Production.

\section{Diary Production in Thailand}

Dairy cattle were an important species as a source of milk and as an income generator for smallholder farmers.
Government therefore set a development plan to support the smallholder dairy industry. Average milk yield form HF purebred cow and HF crossbred cow are 10-25 liters/head/ day (Table 3).

\begin{tabular}{|c|c|c|}
\hline Breed & $\begin{array}{c}\text { Present Milk Yield (liters)/ lactation } \\
\text { 305 days }\end{array}$ & $\begin{array}{c}\text { Potential Milk Yield(liters)/lactation 305 } \\
\text { days }\end{array}$ \\
\hline Holsien Frishien cow & $6,000-7,500$ & 9,000 \\
\hline Cross breed (Frisian x Brahman) & $4,000-5,000$ & 7000 \\
\hline (Frisian x Native Thai) & $3,000-6,000$ & 5,000 \\
\hline
\end{tabular}

Table 3: Diary production in Thailand.

*Buffalo milk only small amount.

\section{Semen Productions in Thailand}

In Thailand, the large scale application of A.I. has played a key role in livestock improvement, particularly in respect of dairy, beef cattle and Buffalo Jamsawat $\mathrm{V}$, et al. This was largely due to the promise of economic advantage that the technique had to offer. Cattle semen production was produce by two sectors as public sector of Department Livestock Development and privet sector companies. The number of sector and their semen production were showed (Table 4).

\begin{tabular}{|c|c|c|c|}
\hline Item & \multicolumn{2}{|c|}{ Semen Producer } \\
\hline Semen Production & Public sector & Private & Total \\
\hline Production Units & 5 & 2 & 7 \\
\hline Production (semen doses produced) million & 1.78 & 3.73 & 5.51 \\
\hline
\end{tabular}

Table 4: Semen production in Thailand.

\section{AI Service in Thailand}

In the early 1989's the livestock sector underwent considerable change. Dairy farmers started to specialize, and this led to an increase in AI for dairy breeds and a fall in AI for commercial crossbreeding. However, Beef cattle and buffalo farmer still breed by sire to improve the animal breeding. Because, the AI servicer of public part cannot contributed to all farmer thought out all part in country. Livestock population and their production potential as well as breeding services coverage is presented as below (Table 5).

\begin{tabular}{|c|c|c|c|}
\hline & & \multicolumn{2}{|c|}{ A.I Services } \\
\hline Specie & Sire & Public (\%) & Private \\
\hline Diary cattle & 12.5 & 56.5 & 16.6 \\
\hline Beef cattle & 64.3 & 19.1 & 7.33 \\
\hline Buffalo & 83.1 & 9.56 & \\
\hline
\end{tabular}

Table 5: Percentage of breeding method by sire and AI service for ruminant species. 


\section{Open Access Journal of Mycology \& Mycological Sciences}

\section{Bovine Embryo Transfer}

Bovine embryo transfer is still in developing stage in Thailand because of lack of awareness among farmers and unavailability of embryos and technical manpower to the farmers. In Thailand bovine embryo transfer is still at experimental stages. No progress has been made in the field of embryo transfer in species other than bovines here in Thailand. In 2015, there are three university of Thailand in the field of bovine embryo transfer and established bovine embryo production lab in Khon Kean, Nakorn Rajchasrima and Bangkok.

Imported and locally produced embryos were transferred into the recipient to improve the gene pool of beef herds and continuous efforts were also made to cope with the changing trends in bovine embryo transfer industry. Three university has been successful to establish the basic techniques involved in superovulation, in vivo bovine embryo production and transfer but it is working with exotic (Charolais and Brahman ). During last decade, Buffalo Research Institute in Thailand were not experiment in embryo production and embryo transfer Duran et al., but local breeds of Thailand still needs to be investigated to enhance genetic improvement in local bovine breeds.

The private farmer and Department Livestock Development of Thailand have not imported embryos and have not been successful in producing calves through embryo transfer. The three Universities has produced invitro blastocyst stage embryo in cattle only in their labs. They cannot produce buffalo embryo for in vivo. 